\title{
Discursive Historical Continuities: Serbian Nationalist Discourse in the Printed Media on the Brink of the First Balkan War (1912) in Comparison with Today Srđan M. JOVANOVIĆ
}

\begin{abstract}
This article explores the 1912 print media in Serbia in their relation to the Balkan Wars, comparing the nationalist topoi with the contemporary age and contemporary national groups. It analyzes the content of several articles printed in papers such as Illustrated War Chronicle (Ilustrovana ratna kronika) and the Serbian newspaper (Srpske novine), juxtaposing their discourse with contemporary Serbian nationalism. The primary sources from 1912 have not been discussed in scholarship, except a few mentions. It shows that after a century since the Balkan Wars has passed, the nationalist discourse has remained more than similar, using the same historical pathos of victimhood and "othering" of the Enemy.
\end{abstract}

Key words: Ilustrovana ratna kronika, Srpske novine, Politika, Serbia, nationalism.

Farewell, father! Farewell, dear mother I cannot stay here any longer

When the king calls to a vengeful battle!

Wait not for me, nor call me any more! May God protect us! Farewell! God bless! And weep not for my young life

Hurrah, comrades! To battle formations! Under the bloody banner! Forward! Forward!

Illustrated War Chronicle (Ilustrovana ratna kronika), 18 October 1912

Nationalism in the Balkans has been studied and analyzed extensively ${ }^{1}$, with a plethora of works concentrating on Serbian nationalism in particular, from

1 Brad K. Blitz. War and change in the Balkans: nationalism, conflict and cooperation, (Cambridge: Cambridge University Press, 2006); Milica Z. Bookman. „Economic decline and nationalism in the Balkans", James F. Brown, Nationalism, democracy, and security in the Balkans, (Dartmouth Publishing Company, 1994); Karin Dyrstad. „After ethnic civil war: Ethno-nationalism in the Western Balkans", Journal of Peace Research no. 49 (6), (2012): 817-831; Pavlos Hatzopoulos. „,All that is, is nationalist': Western imaginings of the Balkans since the Yugoslav wars“, Journal of Southern Europe and the Balkans no. 5 (1), (2003): 25-38; Andrey Ivanov., The Balkans divided: nationalism, minorities, and security, vol. 1, (Frankfurt am Main: Peter Lang Publishing, 1996); Karin Dyrstad, „After ethnic civil war: Ethno-nationalism in the Western Balkans“, Journal of Peace Research, no. 49 (6), (2012): 817-831; Aleksandar Pavkovic. The fragmentation of Yugoslavia : nationalism and war in the Balkans, (New York: St. Martin's Press, 2000); Victor Roudometof and Roland Robertson. Nationalism, globalization, and orthodoxy: the social origins of ethnic conflict in the Balkans, vol. 89, (Greenwood Publishing Group, 2001). 
myriad perspectives ${ }^{2}$. Yet historical research into primary sources (in this case, media from the beginning of the 20th century) is an unending endeavour. In this article, we are concentrating on a corpus of newspaper articles published at the brink of the First Balkan War at the end of 1912. The media discourse that promoted Serbia's joining the war against the Ottoman Empire started by Montenegro (and later joined by Albania, Greece and Bulgaria) is a plentiful source of information on this topic. Juxtaposing the warmongering discourse of a century ago with the rather similar nationalist discourse of this day and age, we concentrate on the discursive elements that have remained almost identical for a hundred years.

Several primary sources are used in the content analysis, namely the 1912 editions of the Politika daily (edited at that time by Vladislav Ribnikar), the Ilustrovana Ratna Kronika (IRK, Serbo-Croatian for Illustrated War Chronicle), edited by Dr. Kamenko Subotić, printed by the Svet bookstore (owner F. Ognjanović) in Novi Sad, as well as the Srpske Novine (Serbian newspaper), at that time the official gazette of the monarchy, printed in the Royal State Press (Kraljevska državna štamparija). All the resources from 1912 were found in the National Library of Serbia (Narodna biblioteka Srbije) in Belgrade, where they exist in digital format as well. Whilst Politika was founded by Ribnikar himself in 1904, the IRK started coming out on 18 October 1912, specifically in order to report on the First Balkan War, as well as to engage in warmongering propaganda, which will be shown in the paragraphs to come. Contemporary resources are nowadays available online, as the Internet has become one of the primary means of disseminating such discourse.

\section{Through the looking glass of the media}

The media can be said to be "for most people the only way in which they ever encounter politics”. ${ }^{3}$ In Chilton's words,

2 Valere Philip Gagnon. „Ethnic nationalism and international conflict: The case of Serbia.“ International security no. 19 (3) (1994): 130-166. Sabrina Petra Ramet, „Nationalism and the 'idiocy'of the countryside: The case of Serbia." Ethnic and Racial Studies no. 19 (1) (1996): 70-87; Ivana Damjanović, Dragan Novaković, and Ivan Obradović. Human rights in the shadow of nationalism: Serbia 2002, (Helsinki Committee for Human Rights in Serbia, 2003); Wendy Bracewell, „Rape in Kosovo: masculinity and Serbian nationalism.“ Nations and Nationalism no. 6 (4) (2000): 563-590; Eric Gordy. Kultura vlasti u Srbiji: nacionalizam i razaranje alternativa, (Belgrade: Samizdat B92, 2001); Katja Kahlina, Local histories, European LGBT designs: Sexual citizenship, nationalism, and „Europeanisation” in post-Yugoslav Croatia and Serbia. Paper read at Women's Studies International Forum., Veličković, Vukša. „Homofobni nacionalizam i kriza maskulinosti u Srbiji." Sarajevske sveske (39/40) (2012): 255.

3 Matthew A. Baum and Tim Groeling. „New media and the polarization of American political discourse." Political Communication no. 25 (4) (2005): 345-365. 
"political parties and government agencies employ publicists of various kinds, whose role is not merely to control the flow of, and access to information, but also to design and monitor wordings and phrasings, and in this way to respond to challenges or potential challenges. The terms 'spin', 'put a spin on' and 'spin doctor' are terms that reflect the public belief in the existence of and significance of discourse management by hired rhetoricians"4.

Even though these particular instances have been exacerbated and strengthened with the development of the media and the rise of the mass media during the $20^{\text {th }}$ century, the principle above is valid for the media of a hundred years ago as well - though the difference is in the fact that at the beginning of the $20^{\text {th }}$ century, we are talking primarily about the press. In other words, "the proliferation of mass communication systems has probably simply amplified the importance of a function that is found not only in contemporary societies but also in traditional societies". ${ }^{5}$ For that reason alone, the media are often dubbed the "fourth power", as "media people act according to their interests and, for different reasons, very selectively pick out the events thought to be worth communicating to the public, thereby strongly influencing the perception and activities of all social actors involved in the system of public communication".

On these pages, we will concentrate on the media-centred nationalist discourse in Serbia on the brink of the Balkan wars in late 1912, drawing a parallel with contemporary discourse, with which numerous similarities will be shown. From a social constructivist point of view, it is of importance to realize that

"the media construction of reality, which signifies the active creation of a public and political agenda, does not here simply formulate the dominant public opinion and the apparent consensus on the subject, but also - in the mutual complementing of media and other discourses - actively lays down the foundation, the primary principles and the legitimacy for the implementation of national and local policies"?

These policies were nationalist both a century ago and today, with the difference that the 1912 discourse can be classified as outright warmongering. A

4 Paul A. Chilton. Analyzing Political Discourse - Theory and Practice, (London: Routledge, 2004).

5 Chilton. Analyzing Political Discourse.

6 Siegfried Jager and Jürgen Link, Die vierte Gewalt. Rassismus und die Medien (Duisburg: DISS, 1993).

7 Vlasta Jalušič. „Xenophobia or self-protection? On the estabilishing of the new slovene civic/ citizenship identity", Xenophobia and Post-Socialism, ed. Mojca Pajnik (Ljubljana: Peace Institute, 2002). 
socially and politically significant policy such as the war against another country needs strong backup and propaganda by those who wish to implement it, and in such an atmosphere, "the media poiesis, one of the main components for creating public policy, acts as a motor for the discourse of 'normality' and the normalization of certain problematic methods of public acting. Through methods of differentiation and distinction it successfully delineates the boundaries of 'acceptability' for the mainline of collective political acting - both by individuals and institutions"

\section{The Kosovo trope}

The Illustrated War Chronicle reported (for lack of better words at the moment) in a strong, belligerent fashion, pregnant with Kosovo-based nationalism. Even in its first issue (18 October 1912), the year 1389 could be seen printed out on the upper left corner, indicating a strong connection to the almost mythical Battle of the Kosovo Field (Ser-Cro. Boj na Kosovu, Bitka na Kosovu Polju) that took place in what is today the fledgeling state of Kosovo in the year 1389, the unending source of Serbian nationalism even in this day and age. As the following examples shall show, most of the discourse of the IRK concentrates on the mythical trope of the Battle of Kosovo, which will not differ overly from the nationalism of the end of the 20th and the beginning of the 21st century in Serbia. There has been a plentiful scholarly production on the topic of Kosovo-based Serbian nationalism'. In order to properly understand it, the Kosovo trope needs to be historically contextualized.

What is known is that in the 14th century, which was the time when the Ottoman Empire expanded to the West and conquered most of the Balkans, what is often considered as the "medieval Serbian state" was located in today's regions from Šmadija (bordering with the rivers Sava and Danube) on the north, including today's Kosovo, and during the reign of Dušan the Strong (Dušan Silni, +1355 ) even into the south, to include portions of Byzantium, today's Albania, Macedonia and a significant part of Greece (nota bene: the state was not even known as "Serbia" at the time, though, - its name was Raška. From the point of view of political science and history, we also have to take care not to understand the medieval concept of the state in the same manner as we see the "state" today). As Trgovčević wrote,

\footnotetext{
8 Jalušič, Xenophobia or self-protection...

9 Philip E Auerswald. „The Kosovo conflict: a diplomatic history through documents.” Refugee Survey Quarterly no. 20 (3) (2001); Židas Daskalovski. Claims to Kosovo: Nationalism and Self-Determination. Understanding the War in Kosovo: (2003): 13-30; Denisa Kostovicova. Kosovo: The politics of identity and space (Routledge, 2005).
} 
"on 28 June 1389 ... this field was the scene of battle between the Turks who were penetrating the Balkans, and Serbs, whose medieval state was located there. According to all evidence, the battle was very violent, and both rulers Turkish Sultan Murat I and Serbian Duke Lazar Hrebeljanović - perished in it, as well as many soldiers on both sides. During the history Serbs were considered as having lost the battle"10.

This battle played a key role in the romanticized national myth-making of the $19^{\text {th }}$ century, and the following analysis will show that it held a central place in nationalist and warmongering discourse both at the beginning of the $20^{\text {th }}$ century, as well as a hundred years later. "The death of the last great Serbian ruler there, and the fact that after that battle the Serbian state started to collapse were conducive for the emergence of the cult. Thus, Kosovo became synonymous with the state's downfall and subsequent slavery over the centuries"11, which will result then in the "five hundred years of the Turkish yoke" trope (debated later). "Thro,ugh chronicles, notes and oral tradition the legend gradually evolved, over time greatly exceeded the significance of the battle and its consequences and spread throughout the territories populated by Serbs, and even among some neighbouring nations" ${ }^{12}$, reaching the status of a historical and political myth. In Kaser's ${ }^{13}$ words,

"above all myth serves to represent historical continuity and enforce the consciousness of the ethnic or national community. Those who are initiated into and accept this created historical heritage come to feel strongly linked to their liminalized mythic ancestors. In the case we are considering here, that of Serbia, the projected effect is that of a spiritual kinship group, sanctified by history and religion with an eternal history."

The moment that Kaser identified as "eternal" was half of a millennium at the brink of the Balkan Wars, and over six centuries today, as the reverberations of the "sanctified history" are still strong, as within the "Kosovo pathos", "the ritual of remembrance symbolizes for many Serbs the ethnic entity of Serbdom, being Serbian and the fight for survival. An essential meaning of Kosovo field is that survival does not depend on victory; even a defeat can be mythologized as the beginning of a period of the never-ending struggle for

\footnotetext{
${ }^{10}$ Ljubinka Trgovcevic. The Kosovo Myth in the First World War (Projekat Rastko GracanicaPec, 1999).

${ }^{11}$ Trgovcevic. The Kosovo Myth in the First World War...

${ }^{12}$ Trgovcevic. The Kosovo Myth in the First World War...

${ }^{13}$ Karl Kaser and Joel M Halpern. „Historical myth and the invention of political folklore in contemporary Serbia," Anthropology of East Europe Review no. 16 (1) (1998): 89-107.
} 
survival, one's folk against all others"14. Many of the abovementioned instances have played important roles in warmongering and nationalistically oriented discourse at the beginnings of the $20^{\text {th }}$ and epy $21^{\text {st }}$ centuries, respectively. Besides the frontally positioned the year of 1389 , the very first issue of the IRK (18 October 1912) boasts a poem about vengeance for Kosovo on its very first page, called "A hail to Serbian kings":

King Petar, king Nikola,

Avengers of the Tzar and Kosovo!

Look at the Serbs, the falcons,

All over the Serbdom wide

As they await you eagerly,

When you shall rise brotherly

And raise the holy Jugović standard,

And draw the saber of the Obilićs,

And shout to Serbian heroes:

„Serbs, brothers, chosen heroes!

„The days of want have already come

„To seek for what once was Serbian

„To avenge the tzar and Kosovo!

„It is the wish of every Serb,

„To retake the tzardom of Dušan!

"Amen, God, quickly, if God allows it!“

Revolving around the trope of the Battle of Kosovo (punctuation given identical to the original within the translation), the poem (of questionable artistic merit) mentions the paradigm "Serb" seven times within the 16-line longform, while "avenging Kosovo" gets mentioned twice. Having in mind that the Battle of Kosovo was considered to be lost, the idea of vengeance can be seen more than often in discourses revolving around it. Kosovo is seen as a lost land, that needs to be reacquired. In Mišković's words, "the slogan 'Revenge for Kosovo' continued to be the Serbian elite most powerful instrument to mobilise the population"15, both literally and metaphorically, both at the beginning of the $20^{\text {th }}$ as well as of the $21^{\text {st }}$ century. As Trgovčević noticed,

"the cult (of Kosovo) particularly flourished during the First Balkan War in 1912, when Kosovo was liberated from Turks and again annexed to the Serbian state. Everywhere in public, it was spoken that the testament of forefathers

\footnotetext{
${ }^{14}$ Kaser and Halpern. „Historical myth and the invention of political folklore in contemporary Serbia..."

${ }^{15}$ Nataša Mišković. Mission, Power, and Violence: Serbia's National Turn (IB Tauris, 2011).
} 
has been fulfilled and revenge awaiting for nearly five centuries done. Gustav Gesemann noted: 'That is Kosovo, the grave of an old Serbian freedom; that is Kosovo, the realization of the new Serbian freedom since 1912, Kosovo whose earth soldiers used to kiss and carry back home in bags, to show to their wives and children." ${ }^{\prime 6}$.

Drawing a tangent to the beginning of the $21^{\text {st }}$ century, we still see a very similar discourse, revolving around the year 1389, which has sustained an almost fully mythological level. One of the innumerable Serb nationalist movements has even used the year for its very appellation, such as the SNP1389 (Srpski narodni pokret 1389, "Serbian national movement 1389") - compare with the IRK and the same year being written on the front page of every issue. In the elaboration of their main goals, the SNP1389 put Kosovo at the very opening, claiming that it is of utter importance to

"free and unite all Serbian lands into one Serbian state (the meaning of 'all Serbian states' comprises: the whole territory of today's Republic of Serbia with its provinces Kosovo and Metohija, as well as Vojvodina, the Republic of Montenegro, Republic of Srpska and the Bosnia and Herzegovina Federation, as well as the area of the occupied Republic of Srpska Krajina with its territorial enlargement, and the northern part of the Republic of Albania).”

This is known as the expansionist nationalist politics of "Great Serbia", which has its roots in the nationalist-romanticist discourses of the $19^{\text {th }}$ century, though drawing its ontology from the fourteenth century ${ }^{17}$. The poem from the IRK even states that "Dušan's tzardom" needs to be "retaken”; as we have already mentioned, the area under the rule of tzar Dušan was the largest territorial expansion ever to have been acquired by a noble of any dynasty ruling medieval Serbia, which coincides with a large part of what the SNP1389 desires. These desires are, in essence, an echo of the organization formed in 1911, the infamous 'Black Hand' (original name "Unification or Death", a group that defenestrated King Aleksandar and Queen Draga Obrenović on 29 May 1903 in a coup), whose

"aim was to push for Serbia actively to take on the role of Piedmont in the unification of all south Slavs. They listed as 'Serb provinces' Bosnia-Herzegovina, Montenegro, Old Serbia (in the Kosovo area), Macedonia, Croatia,

\footnotetext{
${ }^{16}$ Trgovcevic. The Kosovo Myth in the First World War...

${ }^{17}$ Nenad Zakošek. „Democratization, state-building and war: The cases of Serbia and Croatia.“ Democratisation no. 15 (3) (2008): 588-610; Vladimir Žerjavić. „Great Serbia: tragic outcome,“ Globus no. 9 (1998); Bette Denich. „Dismembering Yugoslavia: nationalist ideologies and the symbolic revival of genocide." American Ethnologist no. 21 (2) (1994): 367-390.
} 
Slavonia, Vojvodina and the littoral. Their lobbying and their support of armed bands operating in Ottoman territory increased with the prestige of the army after the Balkan wars"18.

In essence, what was an ideology of a coup d'état a decade before during the Obrenović dynasty, became public policy under the Karađorđević dynasty.

Much of such discourse involves a somewhat inexact vision of the past. In Dikjink's words,

"where nationalist sentiments prevail, the past is always important. It is the main source of arguments and frustration, however, distorted and mythologised ... The person who experiences five centuries of Turkish suppression as a gap in national history rapidly ends up in medieval Great Serbia On Kosovo Day (28 June), the Serbs traditionally commemorate the fall of the Serbian empire at the Battle of Kosovo in 1389 and the start of centuries of Turkish rule" 19 .

As Kritikos wrote, "each of the Balkan nationalisms appropriated and focused selectively on glorified moments of their remote past, in order to achieve national assertion and to bind up their people with folk traditions"20; Serbia was not an exception, and the print media from 1912 exploited this fact heavily.

Even if we go much further back into history, to be noted, the obsession with Kosovo will still be found: "I woke up early, but I did not want to go downtown. The first thing I thought about was that today is St. Vitus Day. In my thoughts, I was more in Kosovo than in my room. It made me sad. I could do almost nothing". As Mišković elaborated, the lines above "were written around 1850 by a young Serb during his studies at a Western university ... In his fantasies, he was transported back to the fourteenth century and took part in the famous battle of Kosovo on St. Vitus Day, 28 June 1389”21. His name was Jevrem Grujić, later becoming a high-ranking politician in Serbia. The obsession with Kosovo was much older than either the early $21^{\text {st }}$ or early $20^{\text {th }}$ century, and as such, it served as a convenient discursive moment for the mobilization of feelings of aggression and staunch nationalism. The Serbian "struggle for independence was linked to the idea of revenge for Kosovo and had a strong religious

${ }^{18}$ Stevan K Pavlovič. A history of the Balkans: 1804-1945 (Longman, 1999).

${ }^{19}$ Gertan Dikjink. National Identity and Geopolitical Visions: Maps of Pride and Pain (London: Routledge, 1996).

${ }^{20}$ George Kritikos. „The geography of nationalisms and human security in the pre-Communist Balkan space" Southeast European and Black Sea Studies no. 11 (4) (2011): 385-401.

${ }^{21}$ Nataša Mišković. Mission, Power, and Violence: Serbia's National Turn (Belgrad: IB Tauris, 2011). 
undercurrent ${ }^{22}$. All these instances are easily identifiable in both the discourse of the IRK and the SNP1389. Even after the two Balkan wars - in which Serbia is considered to have been on the winning side - similar sentiments were plentiful. Emmert wrote about the look backwards of a Serbian soldier right after the Balkan wars:

"The single sound of that word - Kosovo - caused indescribable exciteme-
nt. This one word pointed to the black past - five centuries.... My God, what
awaited us! To see a liberated Kosovo.... The spirits of Lazar, Milos, and all
the Kosovo martyrs gaze upon us. We feel strong and proud, for we are the
generation which will realize the centuries-old dream of the nation"23.

Serbia is, one has to mention, far from being alone in the construction and (ab)use of such historical mythology; similar instances of historical battles (defeats, to be more precise) being hyperbolized in historiography are found in other parts of Europe as well, from the Hungarian Battle of Mohacs (1526), via the Battle of White Mountain for the Czechs (1620) to the divisions of Poland in 1772, 1793 and $1795^{24}$. However, as Todorova noticed, "except for the Battle of Kosovo in Serbia, none of these defeats is a part of the national celebratory ritual" 25 .

In 2015, one of the most active and popular nationalist organizations in Serbia (even entering the Parliament after having created a coalition with the nationalist-oriented Democratic Party of Serbia) are the Dveri srpske (Ser-Cro. "Serbian gateways"). Groups such as the Dveri movement (or the SNP1389) have not been studied often ${ }^{26}$, due to the difficulties in evaluating and quantifying their political impact ${ }^{27}$. However, due to the developed pregnant nationalism present in Serbia, it is becoming more important to assess their discourse, as well as to compare it with the 1912 discourse given above.

More often than not, the Dveri concentrated on the trope of Kosovo. Due to the constant attempts of appealing to the younger population, the Dveri most commonly use the internet as their favoured media. In their section entitled "The Foundations of Our Politics", Kosovo figures as one of the most important issues. Just one example is their publishing of the known anti-Semite and

\footnotetext{
${ }^{22}$ Mišković. Mission, Power, and Violence...

${ }^{23}$ Thomas A Emmert. Serbian Golgotha-Kosovo, 1389 (East European Monographs, 1990).

${ }^{24}$ Maria Todorova and Slobodanka Glišić. Dizanje prošlosti u vazduh: ogledi o Balkanu i Istočnoj Evropi (Belgrade: Biblioteka XX vek, 2010).

${ }^{25}$ Todorova,Glišić. Dizanje prošlosti u vazduh...

${ }^{26}$ Barbara Wiesinger. „The Continuing Presence of the Extreme Right in Post-Milošević Serbia." Balkanologie. Revue d'études pluridisciplinaires no. 11 (1-2) (2008).

${ }^{27}$ Roger Eatwell. Ten theories of the extreme right (2003).
} 
NSDAP-collaborator, the vladika Nikolaj Velimirović, and his text about Kosovo and what he dubs "the Knights of Kosovo": "Would it not be useful for us to put ourselves forth to judgment under the court of the Knights of Kosovo?"28. Many texts in which what is dubbed "the defense of Kosovo" figures prominently are often published, yet the alleged "defense" entails almost exclusively and always nothing more than protests about the recognition of present-day Kosovo as a standalone state, and, more recently, against the recognition of Kosovo by UNESCO ${ }^{29}$.

Other institutions and individuals on the right side of the political spectrum are also rather energetic and prolific when it comes to "defending" Kosovo. The Foundation for Strategic Culture (Ser-Cro. Fond strateške kulture), for instance, published an elongated expose on Kosovo by Aleksandar Pavić (also carried over by the Dveri on their official webpage):

"However, Kosovo, no matter how much our internal and external enemies tried to diminish it, is not a simple material fact, a common interest, a common part of the territory. If it were so, the collective spirit of the nation, even in this inglorious moment in history, would not prevent even the "most pragmatic" of the political class ... to try to support openly its independence and acknowledgement as a separate state. (...) Kosovo keeps us collectively, obviously, in spiritual life, it reminds us of higher spheres of being...."30.

Having in mind that Serbia was on the winning side of both Balkan wars, and having in mind that it did succeed in acquiring Kosovo in the First Balkan war (dubbed even then as "freeing" it), the only relevant difference between the discourses of 1912 and 2015 is about from whom Kosovo should be "freed" - once from the Ottoman Empire, now it had to be freed from itself. An important spin was added today, being that Kosovo made a self-declaration of independence, making it difficult for it to be "freed" from itself, so the contemporary nationalist core often sees Kosovo as "under occupation" by "foreign elements", from the Albanians, via simply by a very undefined "West", to the USA.

${ }^{28}$ Dveri. Vidovdan. Beseda vladike Nikolaja 2015c [cited 3 March 2015. Available from http:// www.dverisrpske.com/sr/program/temelji-nase-politike/2634-vidovdan-beseda-vladikenikolaja.html.

${ }^{29}$ Dveri. Potpisi za sprečavanje prijema Kosova u UNESCO 2015b [cited 5 March 2015. Available from http://dverisrpske.com/sr/prenosimo/7251-potpisi-za-sprecavanje-prijema-kosova-u-unesco.html.

${ }^{30}$ Aleksandar Pavić, Vladimir Kostić i Kosovo: veština naspram vrline. (Fond strateške kulture, 2015) http://www.fsksrb.ru/fond-strateske-kulture/ostalo/vladimir-kostic-i-kosovovestina-naspram-vrline/. 


\section{Orientalism and suffering}

The same issue of the IRK boasted the title "War for freedom and civilization" on its title page:

"We are writing a chronicle of the war for freedom and civilization in the European part of Turkey.

We are writing a chronicle of great events in the Balkans.

We are writing a chronicle of a great tragedy, of blood and death.

We are writing a chronicle of the suffering of those who die, and those who live.

We are writing a chronicle of the great hopes of those who give their lives for hope.

We are writing a chronicle of those who do not die, but suffer greatly.”

The very title suggests a somewhat orientalist discourse, in which the "Other" from the East is represented sub-textually as "uncivilized": note that the Ottomans are not a single time directly called "uncivilized", but the battle against them is dubbed to be a "battle for civilization". As Ignjatović wrote, there is a "widely-shared image of the Turks as "uncivilized and barbarous" 31 . Todorova has noticed that, in addition to a "balkanist" discourse presented by the Occident, there is a staunch balkanism present even in the Balkans, where the "Other" is taken from the Balkans themselves. She calls it "a process of 'chain orientalising of the Other' in the Balkans, a sordid custom of the representation of the neighbour as 'more oriental' than us", which is "characteristic for the broader situation of the spirit I have dubbed 'balkanism'"32. The anaphoric construction with the repetition of "We are writing a chronicle" strengthens the importance of the piece and of the daily itself by giving it an artistic air, while the victimization of the self can be seen in the pictures of "blood", "death", "tragedy" and "suffering" ("our" blood, "our" death etc). The lengthy article continues:

"The peoples in Turkey, the Serbs, have no life in Turkey. It is the life they need. It is the life they long for. A full life, true, free, cultural and civilizational. There is no such life in Turkey. Turkey oppresses a great part of the lands of Europe, a great number of European peoples, many Serbs, young and wanting of life, freedom and work. It oppresses, suffocates, puts back and deforms a race that is new, original, young and full of life. Death becomes the source of life. The energy and will of the new race shall win, today or tomorrow."

${ }^{31}$ Aleksandar Ignjatović. „Images of the Nation Foreseen: Ivan Meštrović's Vidovdan Temple and Primordial Yugoslavism," Review of Images of Imperial Legacy: Modern Discourses on the Social and Cultural Impact of Ottoman and Habsburg Rule in Southeastern Europe, Eds. T. Sindbaek and M. Hartmuth, The Slavonic and East European Review no. 90 (3) (2012):527530. doi: 10.5699/slaveasteurorev2.90.3.0527.

32 Todorova, Glišić, Dizanje prošlosti u vazduh... 
What we see in the paragraphs above is described by Sundhaussen as the "myth of the golden pre-Osmanic era, of a clear and organic nation, of national rebirth, of the myth of Kosovo, of the hajduks, and the myth of suffering"33. It should be noticed here that, as Todorova elaborated,

"it is very difficult to make a structural difference between such myths and the 'golden age' myth of antiquity, the myth (and practice) tied to the $\mathrm{Nu}$ renberg laws of the thirties and the ius sanguinis, the myth of Rome (as is seen in Italian national ideology, together with the myth of the Roman Republic, Roman Empire, as well as the myth of the Papacy, the myth of the Battle of Poitiers (both the one in the eighth and the one in the fourteenth century), the myth of the Valkyries and the myth of the fortress under the siege of enemies" 34 .

It would be wise to note that the orientalising discourse was far from being present only in Serbia, or among the peoples of the Balkans who rose against the Ottoman Empire. Svetozar Tonjoroff, in a 1912 article published by the North American Review, wrote how "these minor peoples [were] tugging at the leash in their desire to fly at the throat of their old oppressor", mentioning even "the hazards of Ottoman rule [of] the Christian populations of Macedonia and Thrace" 3 .

Going back to the source material, we can turn to yet another issue of the Illustrated War Chronicle, this time from 25 October 1912, in which discourse of the same type can be seen, concentrating on the "Turkish yoke" and the years of "suffering" for the Serbian "nation", as well as of the ubiquitous "vengeance for Kosovo" as a point of mobilization:

"There has been suffering for five centuries. There has been torture for five hundred years. It had been a sea of suffering. The whole nation lived in agony. The Serbian nation. Turks tortured it, for the Serbian nation slaved under the Turks. Even those who were out of the reach of the Turkish government suffered. We all know it because we suffered. For whilst we were still suckling on the mother's breast, they sang to us songs of Kosovo and slavery. Then we were told stories about slavery and suffering. When we learned to read, we read folk poetry, we read them to ourselves and others, and the feelings of suffering and longing for vengeance crept into our soul. All our national soul filled with bile. A sea of bile was spilled over our people. In addition to that, many others oppressed us, and we rolled about under the weight of mighty

${ }^{33}$ Holm Sundhaussen. 1999. Europa balcanica. Der Balkan als historischer Raum Europas. Geschichte und Gesellschaft no. 25 (H. 4): 626-653 (1999).

${ }^{34}$ Todorova, Glišić, Dizanje prošlosti u vazduh...

${ }^{35}$ Svetozar Tonjoroff. „The War in the Balkans.“ The North American Review no. 196 (685) (1912): 721-730. 
and hard blows. We were the anvil on which heavy and too heavy strikes pounded. The anvil was mighty and hard, and as the blows became stronger, it became even harder. Our suffering made us stronger. We became a strong nation, toughened up, ready for life and strife. Ready for the vengeance over Kosovo. And then our time came. Our time is today."

In the passages above, we see metaphors galore; once again, not confined to the discourses of the Balkans. The repetition of instances with negative connotations, such as "slavery", "suffering", "longing for vengeance", emphasizes the victim mentality that is supposed to support and sustain the warmongering climate of the age. The aforementioned article by Tonjoroff wrote, among other issues, how "the telegraph-wires flashed to the breakfast-tables of chancellors and permanent under-secretaries the astonishing news that the forked lightning was already riving the thunder-clouds that had hovered over southeastern Europe since the father of the oldest statesman of them all was in swaddlingclothes" ${ }^{36}$. There is talk about the "national soul filled with bile", as well as a vivid metaphor of the "anvil", striking down on the victim, Serbia, that often gets personified as a discursive strategy by which it gets easier to promote "defense", where in reality, an attack is about to take place.

The 'five hundred years under the Turkish yoke' is called one of the "shabbiest general moments of nationalist discourse" in Serbia by some authors ${ }^{37}$, as well as "the mythical aura of the Turkish yoke" 38 , which was used even in the official language of scholarly publications in the aftermath of the Balkan wars („Belgrade itself fell once more under the Turkish yoke“) ${ }^{39}$. It is almost omnipresent in today's banal nationalist discourse, so statements such as "small wonder, since we have been under the Turks for 500 years" ${ }^{\prime 40}$ in a student's impression, or "is it a genetic remain due to the 500 years of life under the Turks" ${ }^{\text {"1 }}$ in the view of a popular security analyst Miroslav Lazanski are easy to find. The banality of such a way of thinking is seen in the context, for none of the two abovementioned texts directly propound Serbian nationalism - the five centu-

36 Tonjoroff. „The War in the Balkans“...

${ }^{37}$ Dejan Ilić. „Beg iz ropstva,“ Peščanik (2014), http://pescanik.net/beg-iz-ropstva/.

${ }^{38}$ Aleksandar Ignjatović. „Images of the Nation Foreseen: Ivan Meštrović’s Vidovdan Temple and Primordial Yugoslavism.".

${ }^{39}$ Vasa Stajić. „Svetozar Miletić and the Liberal Idea among the Jugoslavs.“ The Slavonic Review no. 5 (13): 106-113 (1926).

${ }^{40}$ Bojan Arambašić. „Istanbul prekretnica života - priča studenta sa prakse,“ IAESTEBIH 2015 [cited 17 March 2017. Available from http://iaeste.ba/istanbul-prekretnica-zivota-prica-studenta-sa-prakse/.

${ }^{41}$ Dveri. 15 March 2015. Doktrina ministra Gašića 2015a15 March 2015]. Available from http://www.dverisrpske.com/sr/prenosimo/6514-doktrina-ministra-gasica.html. 
ries under the Turks is simply a given. Putting the phrase into a broader context, the trope of the "Turkish yoke" was and is to be found in many other countries, from Romania to Armenia ${ }^{42}$ or Bulgaria ${ }^{43}$.

The daily Politika, on 18 September 1912, published "A response to Turkey" on its front page in which it claims that "in Turkey ... things that are impossible at the basic level of human culture happen daily". The text called for the protection of the "Christian population", in an antemurale pathos often used against Islam. According to this text, Serbia has "cultivated the relations of the most correct of neighbors" with the Ottoman Empire, yet now "the Serbian government was forced to mobilize", showing what van Dijk calls captatio benevolentiae ${ }^{44}$, by which We are "good", and the "enemy" is "bad". Neither the Ilustrovana Ratna Kronika, nor the Srpski Glasnik, nor Politika, however, explained or elaborated on this "horrible" treatment of the "Serbian" or "Christian" population. Statements such as those above were exclusively given in a declarative discursive manner, without details of any kind. Another revealing declarative paragraph can be found in the IRK from October 18, 1912, entitled 'An introduction to war':

"Why: a war against the Turks? Because: Turkey in Europe is a state of anarchy, a medieval state, Asian. In it, there is utter lawlessness. Freedom, personal and property is not protected. There are no laws or justice. The designations of this state are robbery, abductions and murder. It is a shame that such a state exists in Europe in the twentieth century. Turkey oppresses large areas, and there are many peoples in it. There is only up to a million Serbs. These peoples, these Serbs, lived in slavery. And the land in Turkey lived in slavery. The land was dead capital. Turkey was unproductive. The time was a night to make of it a European state. It (Turkey) could not do it on its own. It gave a great generation. Those were the Young Turks. They wanted to make a European state out of Turkey; they wanted it, but they could not succeed. They were energetic, they were patriots, but there was nothing to be done with Turkey."

The declarative, uncorroborated nature of the text is all-permeating. From anarchy and Ottoman "medievalness" via lawlessness to abduction and murder, all these instances are simply proclaimed, declared, put forth, without a shred of actual evidence to corroborate the claims. The addition of the Young Turk movement served to strengthen the "backwardness" of the Ottoman Empire, showing that it could not reform itself even from within.

${ }^{42}$ Raymond E Crist, „Cross Cultural Currents in the Near East,“ American Journal of Economics and Sociology no. 50 (2) (1991): 255-256.

${ }^{43}$ Ralph Warburton. „THE WORLD'S NERVE CENTRES.“ The Journal of Education no. 68 (14 (1699)) (1908):399-400.

${ }^{44}$ T. A van Dijk. „Discourse and Manipulation.“ Discourse \& Society no. 17 (3) (2006): 359-383. 
Contextualizing the mentioned historical events, we see that the time was fruitful for military action against an already decaying Ottoman Empire, especially having in mind the unrests in Albania and the Ottoman military action in Libya. As Pavlowitch wrote, "the Ottoman army had been weakened by the war in Libya, by domestic controversies, by financial problems and by desertions. Its forces in Europe were outnumbered by those of the Balkan allies"45. If ever there was a time to strike, it was in 1912, and the government of the Monarchy of Serbia seemed to have understood this more than well. After an extended border dispute with the Empire, Montenegro was the first to declare war in October 1912, followed by Serbia, and then by Greece and Bulgaria. The discourse propounded by the government via the media had to justify military action against a politically accepted sovereign state, and thus a strong warmongering pathos emerged in the media as a means to that end.

\section{The Call to War}

His Royal Majesty, King Petar I, proclaimed war against the Ottoman Empire in November 1912. This announcement was jubilantly reproduced in the IRK on 8 November. It represents a combination of the instances presented and analyzed above, as we see an amalgamation of the Kosovo trope, the Great Serbia, the victim mentality - all in one text. When the elites themselves enter a warmongering, nationalist discourse, it is of small wonder to see it flourish so successfully.

"A Call to War By His Majesty, the King of Serbia, Petar I, to the Serbian people: Newest events put forth the salvation of the fate of the Balkan peninsula, and with it, the fate of Old Serbia, that celebrated but sad mother of our kingdom, where the historical core of the Serbian state of the kings and tzars of old lies, where the famed capitols of the Nemanjićs are: Ras in Novi Pazar, Priština, Skoplje, Prizren; where our brothers live, our brothers by: blood, language, customs, mentality, wishes and cravings. The conquering and bigoted ottoman rule has been exterminating these brothers of ours for centuries. From the Berlin Congress to this day and age, killing, abduction to Asia, and until the very last days, forced movement, conversion of males and females into Turks, unacknowledging our faith and language, the Serb name, were the foundation of Turkish governance. ... Even the very rules of customs in Turkey have unreasonably prohibited trade ...”

What is also of notice is the gendered, feminized vision of "mother Serbia", a trope often used in nationalist discourse ${ }^{46}$, emphasizing the vulnerability of

${ }^{45}$ Stevan K Pavlovič. A history of the Balkans 1804-1945 (Longman, 1999).

${ }^{46}$ Amena Mohsin, „Gendered nation, gendered peace.” Indian Journal of Gender Studies no. 11 (1) (2004): 43-64; Tamar Mayer. Gender ironies of nationalism: Sexing the nation (Routledge, 
femininity in a patriarchal Weltanschauung, stressing, thus, the need to 'defend' it. Additionally, history is put into the spotlight as well by enumerating important medieval cities of the old Nemanjić dynasty.

The Srpske Novine (Ser-Cro. "Serbian newspaper"), the official gazette of the Monarchy at that time, printed the sermon given by King Petar on 20 September 1912, in which the sovereign expounded on the reasons behind the war against the Ottoman Empire. Several instances were mentioned, among others "the position of our compatriots in the Ottoman Empire", which has "always been a cause of worries in the Kingdom of Serbia". Note that the idea of "suffering" of the "Orthodox Serbs" under the "yoke of the Turks" does not have a confirmation within contemporary historiography. What is more, even when the Ottoman Empire slowly took over parts of the Balkans from the fourteenth century onwards, historians have noticed that to the contrary, some of the serfs and significant parts of the population felt relieved, having in mind that they used to pay heavier taxes under their former rulers ${ }^{47}$. King Petar used an appeal to emotion in his sermon often, claiming, among other issues, that "we were forced to conquer the strongest, simplest emotions of the whole nation in relation to the "increasingly stronger cries of our downtrodden brothers, who face ultimate extinction". A week later, the Srpske Novine published a reply to the sermon, written by the People's Parliament, in which the Parliament approved the decision to go to war, echoing the King's sentiment: "the desperate condition of our compatriots in the Ottoman Empire has ever given heavy concerns both to the people and the governments of the Kingdom of Serbia”. Note the populist instance in which the sentiment of the people is equalled to that of the government.

Today, nationalist and xenophobic web portals in Serbia still see Turkey in the same vein. A revealing text published by Intermagazin claimed the following in 2016:

"Dear Turks! I am fond of you because we broke free from you, and because several states and borders with people such as us separate us from you, people who have, like us, Serbs, been your slaves. For 500 years. ... we have churches and monasteries from the time when we were your slaves ..." ${ }^{\text {48 }}$.

The more extremely oriented Stormfront see their members post numerous forum threads "exposing" Turkey as a century-old enemy of Serbia, among

2012); Kif Augustine-Adams. „Gendered States: A Comparative Construction of Citizenship and Nation," Va. J. Int'l L. no. 41:93 (2000).

${ }^{47}$ Holm Sundhaussen. Europa balcanica. Der Balkan als historischer Raum Europas. Geschichte und Gesellschaft. (1999); 25: 626-53.

${ }^{48}$ RAndrić. „PISMO TURCIMA: Daleko vam lepa kuća! Mi Srbi, dobro znamo ko ste vi! Neka vas neko drugi miri sa Rusima!“Intermagazin: (2016, accessed 16 February 2017). 
other issues, writing how "Turks and Jews were together against Serbia"49. The social media active nationalist portal Srbin.info, for instance, wrote about the child levy, the so-called devsirm ${ }^{50}$, trying to present it as if the devsirme was localized to Serbia. The Nova srpska politička misao portal, one of the strongest points of Serbia's contemporary Right Wing, published Milanko Šekler's own view of the Turkish rule, entitled "The child levy, now and then".

The daily Politika, known to have been loyal to any government for over a century now (as it still exists), published a text with the title "Mobilization" on 18 September 1913. According to this text, "Serbia has been put into a hard and fateful situation" as the mobilization against the Ottoman Empire was a "necessity", adding that "Turkey got what it deserved". Turkey will be fought against by "one of the best armies in the world", which is how the IRK (9 May 1913) described the Serbian army.

\section{Conclusion}

Kritikos summed up the nationalist topos of the glorified past succinctly, saying that

"the cultural formulations from a remote glorified past and the emotional appeal of nationalist mobilization, the association with a specific 'homeland', the myth of common descent, and the 'continuity' between an ethnic past and a national present became intrinsic to the Balkan identification as well as to the creation of some of the main attributes of ethnic community"51.

This continuity is all-permeating and ubiquitous, linking the warmongering print media discourse from 1912 with the same pathos which is being used at the beginning of the $21^{\text {st }}$ century. The (mis)use of history is a crucial, intrinsic element in the discursive mobilization of support by nationalist groups, politicians and individuals. The more primary material we find from the past, the better shall our understanding of the present become. This is why Patrick Geary stressed that the prime area of interest for historians should be the countering of a twisted version of the past ${ }^{52}$, something that can be achieved with rigorous analysis of the past, via the use of an almost endless corpus of primary material.

${ }^{49}$ Stormfront.org. Turci i Jevreji, zajedno protiv Srba. 2007.

${ }^{50}$ Srbin.info. Danak u krvi: kako su Turci vladali Srbima. Srbininfo.

${ }^{51}$ George Kritikos. „The geography of nationalisms and human security in the pre-Communist Balkan space." Southeast European and Black Sea Studies no. 11 (4) (2011): 385-401. doi: 10.1080/14683857.2011.632541.

52 Patrick Geary. The myth of nations: the medieval origins of Europe (Princeton University Press, 2002). 
The same can be said about the media from the beginning of the $20^{\text {th }}$ century in Serbia, as much as about the media from the $21^{\text {st }}$ century. Encomiast discourse about the Self, ignoring or satanizing about the Other. The most productive pressure point is seen in the case of Kosovo, which was a central point of nationalist discourse during the Balkan wars as much as it has become the same anew from the 1990s, carrying on into the $21^{\text {st }}$ century. What we see here is a century on concetrating on a mythical sociopolitical instance. It is mythical as it is not based in historical reality, and, for lack of other words, dangerous and detrimental, as the country has had much issues in moving forward with the EU accession absent an agreed border. Without knowing whether Kosovo is a part of Serbia or not, the country is finding it rather difficult to go forward, and political players keep using the issue to evade other, more pressing issues, such as the current attacks on the free media and the diminishing freedom of speech and the press, galloping poverty, corruption, crime, and a plethora of other, deterimental issues that are nowadays framing Serbia as a captured state under the government of Aleksandar Vučić.

\section{Rezumat}

Acest articol explorează presa scrisă din 1912 din Serbia privind războaiele din Balcani, comparând discursul naţionalist cu epoca contemporană. În acest studiu sunt analizate conținutul mai multor articole tipărite în lucrări precum Cronica de război ilustrată (Ilustrovana ratna kronika) și ziarul sârbesc (Srpske novine), juxtapunând discursul lor cu naţionalismul sârb contemporan. Studiul arată că după un secol de la trecerea războaielor balcanice, discursul naționalist a rămas mai mult decât similar, folosind acelaşi discurs istoric al victimizării şi al „alterării” inamicului.

Cuvinte cheie: Cronica de război ilustrată, Srpske novine, politica, Serbia, naționalism.

Srđan M. Jovanović, College of History, Nankai University, China, e-mail: smjovanovic@nankai.edu.cn 